\author{
ADVANCED INTERNATIONAL JOURNAL OF \\ BANKING, ACCOUNTING AND FINANCE \\ (AIJBAF) \\ www.aijbaf.com
}

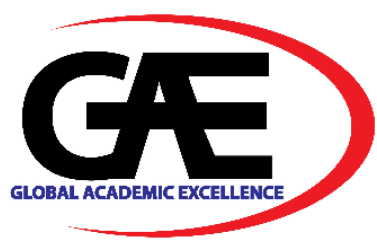

\title{
VALUE-BASED INTERMEDIATION AND REALISATION OF MAQASID AL-SHARIAH: ISSUES AND CHALLENGES FOR ISLAMIC BANKS IN MALAYSIA
}

\author{
Wan A'tirah Mahyudin ${ }^{1 *}$, Romzie Rosman ${ }^{2}$ \\ 1 Faculty of Economics and Muamalat, Universiti Sains Islam Malaysia \\ Email: wanatirah.m@gmail.com \\ 2 Institute of Islamic Banking and Finance, International Islamic University Malaysia \\ Email: romzie @iium.edu.my \\ * Corresponding Author
}

\section{Article Info:}

Article history:

Received date:08.11.2020

Revised date: 15.11 .2020

Accepted date: 17.11 .2020

Published date: 01.12 .2020

\section{To cite this document:}

Mahyudin, W. A., \& Rosman, R. (2020). Value-Based Intermediation and Realisation of Maqasid AlShariah: Issues and Challenges for Islamic Banks in Malaysia. Advanced International Journal of Banking, Accounting, and Finance, 2 (5), 34-44.

DOI: 10.35631/AIJBAF.25003.

This work is licensed under $\underline{\text { C B BY 4.0 }}$

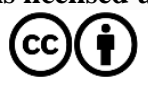

\begin{abstract}
:
The expectation of stakeholders towards Islamic banks has changed and goes beyond avoiding riba and compliance with Shariah but to become value-based intermediaries and fulfil the objective of Shariah Many studies argue that the goals of Islamic banking should not be restricted to maximizing shareholder wealth but should also entail raising the standard of living and welfare of the community. This paper aims to discuss the issues, trends and challenges for Islamic banking in Malaysia towards satisfying various stakeholders' needs through the implementation of value-based intermediation (VBI). VBI has been firstly introduced by Bank Negara Malaysia in 2017. In VBI, maqasid alshariah is established as the fundamental framework in deciding the underlying values, moral compass, and goals in Islamic finance. Thus, realisation of maqasid al-shariah has created its own challenges in VBI implementation. Some earlier studies have discussed issues related to the principles and approaches related to VBI but neglecting other important mechanisms to drive its successful implementation. This review paper highlighted that corporate governance and performance measures are essential elements in VBI implementation. Future studies are encouraged to further explore the possible indicators that can fairly assess the efforts of Islamic banks in satisfying stakeholder needs in line with maqasid al-shariah. Further studies in corporate governance also deemed important to establish the relationship between the key corporate governance players and stakeholder management in Islamic banks.
\end{abstract}


Keywords:

Value-Based Intermediation, Value-Based Banking, Stakeholder Management, Maqasid Al-Shariah, Islamic Banks

\section{Introduction}

Islamic banking is a subset of financial services and have been the fastest growing sector in financial market especially in Malaysia. Financial services should reflect very speedily to the potential financial crisis caused by various factors. Currently, the issue of Covid-19 pandemic also harms and require financial services to react promptly. This pandemic creates the high demand for realization of maqasid al-shariah which has been propagated in one of BNM initiative for Islamic banking institutions known as value-based intermediation.

Malaysia has witnessed progressive development in Islamic finance sector especially Islamic banking. Throughout years, the Islamic banking assets grow positively and much better than conventional banking (Febrian, $\mathrm{Ng}$, \& Al Natoor, 2019). The Fitch Ratings reported that Islamic banks' financing grew by 11\% in 2018 (2017: 9.3\%), outpacing that of conventional banking's 3.3\%. It was also expected that half of Malaysia's banking assets to be Islamic in next decade (Elffie Chew, 2020). However, despite the struggle to maintain its growth in the competitive financial market, one of the major challenges in Islamic banking industry is to satisfying stakeholders needs and expectations and to fulfil what has been intended by Shariah. Many has argued that Islamic bank's direction should go beyond profit oriented (Abdul Aris et al., 2013; Hasan, 2019; Mohammad \& Shahwan, 2013; Mohammed \& Taib, 2015; Myers \& Hassanzadeh, 2013). The introduction of value-based intermediation (VBI) initiative by Bank Negara Malaysia is a valuable initiative to address this issue.

As per BNM strategy paper on VBI, VBI is defined as "an intermediation function that aims to deliver the intended outcomes of Shariah through practices, conduct and offerings that generate positive and sustainable impact to the economy, community and environment, consistent with the shareholders' sustainable returns and long-term interests. VBI promotes a more holistic observation of Shariah, beyond Shariah compliance, i.e. ensuring Islamic banking offerings and practices not only comply with Shariah requirements but also achieve the intended outcomes of Shariah" (Bank Negara Malaysia, 2018). In VBI implementation guide, several implementation issues and challenges have been highlighted. Among them are the lack of autonomy and gap in leadership in Islamic subsidiaries, risk management capabilities, maintaining the market competitiveness and changing the mindset of customers and investors (BNM, 2018).

Despites these issues and challenges, Mahadi, Mohd Zain and Engku Ali (2019) revealed a positive acceptance of VBI by Islamic banks in Malaysia. They investigated some application of VBI concepts in Islamic banking products and revealed that some local Islamic banks uphold the VBI values in their products offering especially in Islamic social finance instruments. Arshad, Muda, Nair and Baharudin (2018) argued that value-based initiatives have been adopted by Islamic banks in Malaysia even before the issuance of the strategy paper by the central bank. For example, the funding of microfinance to small and medium enterprises, financing real sector economy, waqf and giving of benevolent loan. However, the 
implementation may have been not consciously directed towards achieving maqasid alshariah.

There are many need to be done with value-based intermediation. An integrated reporting is one of it. Ramli and Muhamed (2018) examined the quality of integrated reporting in two fullpledged Malaysian Islamic banks for the year ended 2017. They revealed that both Islamic banks have a different level of reporting quality in certain reporting area, but very good in disclosing the business strategy and resources allocation. However, they found that VBI related strategy is not being integrated in the reporting practices.

The purpose of this paper is to review the ongoing issues facing Islamic banking sector in satisfying various stakeholders needs and to delivering the intended outcome of Shariah. A literature survey and document analysis are conducted to understand the arising issues and challenges faced by VBI to address the abovementioned issues. Some earlier studies have discussed issues related to the principles and approaches related to VBI but neglecting other important mechanisms to drive its successful implementation.

\section{Issues and Trends}

\section{Value-based Intermediation (VBI)}

VBI is an initiative introduced by Bank Negara Malaysia to promote value-based banking activities. VBI is not a new theme that promotes value-based practices, but it has been motivated and learned from what has been introduced by the global practices known as Valuebased Banking (VBB). Value-based banking has been founded in 2009 under the initiative of Global Alliance for Banking on Values (GABV). A number of countries around the world that are committed to positive change in the banking sector have participated in the GABV. They basically have a shared mission to use finance to achieve sustainable economic, social and environmental growth, with a focus on helping people realise their potential and build stronger communities. The implementation of value-based banking showed a positive impact to real economic sectors as well as provide a better financial position to financial institutions where it was reported that institutions that participate in VBB earned better financial returns than those are not (GABV, 2017). Recently in 2018, one of the Malaysian Islamic banks which is Bank Muamalat Malaysia Berhad (BMMB) has joined GABV as member to foster its target to be the champion in becoming a socially responsible bank as well as promoting ethical banking. BMMB also recorded as the first Islamic bank that is accepted as GABV member. This shows a positive development in the Islamic banking industry that should be pursued by all parties.

Generally, VBI shares some similarities to ethical finance, Environmental, Social and Governance (ESG) and Socially Responsible Investment (SRI) concepts where they are measuring the sustainability and ethical impact of an investment in a company or business. Nevertheless, VBI has a distinguishing feature in that the maqasid al-shariah is the fundamental framework in deciding the underlying values, the moral compass and the goals in Islamic finance.

In addition to delivering an impact-based banking, implementation of VBI is envisaged to be an important mechanism to boost the performance of Islamic banks (Zainul, 2019). With this projection, this means that implementation of VBI can be a remarkable step in realising the full 
potential of Islamic finance. Nevertheless, in 2017, it was reported that annual growth rate of Malaysian Islamic banking has reduced from double-digit to single-digit expansion (BIMB, 2017). Many suggested that Islamic banking needs to explore new ways to support its growth and play a greater role in value-based intermediation, beyond existing credit intermediation positions, to provide a more active contribution to wider economic and social development (BIMB, 2017; BNM, 2016). Although VBI implementation has been focused in Malaysia, David Korslund the senior advisor at GABV believes the BNM initiative on VBI will be learned and go far beyond Malaysia (Islamic Finance News, 2018). Therefore, this paper should be worthy for industry players around the world to take precautions and build motivation in developing strategy for implementing value-based banking.

\section{The Realisation of Maqasid Al-shariah}

Realising the objectives of Shariah has been given much attention by various parties especially in Islamic financial sector. In Malaysia, for example, the government, policy maker and industry players have initiated various initiatives to deliver the intended outcome of Shariah. In 2015, the government of Malaysia has introduced an index known as the Malaysian Shariah Index (ISM). The index was developed as to measure the commitment of the Malaysian government to achieve the objectives of Shariah via its policy development and implementation. The introduction of the index shows that maqasid al-shariah framework is an important basis to govern the organisational practices of any kind of institution to ensure the protection of public interest and welfare. In Islamic financial sector, the introduction of VBI by Bank negara Malaysia act as a game changer to realise the objectives of Shariah. Islamic financial institutions particularly Islamic banks are expected to deliver the intended outcome of Shariah by implementation of VBI agenda and application of Shariah values in its business conduct and products offering.

Generally, maqasid al-shariah concern about public interest and welfare. The classical and contemporary jurists defined maqasid al-shariah in a various spectrum and it has been frequently classified into two; general objectives (maqasid ammah) and specific objectives (maqasid khassah). Ibn Ashur, one of the contemporary scholars in maqasid al-shariah stated that the general objectives of Shariah are to preserve the social order of communities and ensure their health and to remove corruption in all kinds of human activity (Ashur, 2006). While, Muhammad Hashim Kamali stated that, the general objectives of Shariah is to ensure justice and educating individuals (tahdib al-fard) (Kamali, 2009). Besides the general objectives of al-Shariah, scholars identified that Shariah possesses some specific objectives in a specific discipline, for example, concerning the different spheres of human transaction. Ibn Ashur is among the few scholars who devotes his particular attention to the specification of maqasid alshariah in human dealings i.e. family matters, financial transactions, employment and employees, judiciary and giving of testimony, gifts and donations, and penalties. Additionally, he also provides a longer discussion to financial matters as compared to the other five topics. The discussion includes distribution of wealth in the hands of many people as possible. In a recent study, Hassan and Nor (2019) have discussed the relationship between VBI, Shariah and its objectives. They revealed many evidences from Quranic and Hadith that support the principles underlie VBI strategies.

In realising maqasid al-shariah, many efforts need to be done. Mohammed, Razak, and Taib (2008) suggested that Islamic banks should perform in three maqasid dimensions; educating 
individual (tahdib al-fard), establishing justice ( $a l$-adl), and promoting welfare (maslahah). Meanwhile, other studies highlighted that Islamic banks should contribute to the preservation of life, religion, intellect, posterity, wealth and ecology (Asutay \& Harningtyas, 2015). The realisation of these objectives can be done through the banks business activities and product offering such as investment in real sector, financing to a small-and medium enterprises (SMEs), training provided to employees, giving of benevolent loan and many others. Some of these examples have also been proposed as the VBI key performance indicator. However, previous studies reported that the current performance of Islamic banks is still less diversified and recorded a low contribution to the maqasid spectrum, especially in the social entity, preservation of intellect, posterity and ecology (Asutay \& Harningtyas, 2015). Additionally, BNM also reported a declination in business financing growth for small and medium-sized enterprises in 2017 showing that there is a shortcoming in the value-creation for wider stakeholders (BNM, 2017). Thus, diversifying the output of Islamic banks and continuous promotion of value-based activities are essential to achieving the objectives of Shariah.

\section{Stakeholder Management and Corporate Governance}

Consistent with the global practices, the introduction of VBI as new strategic plan also aims at increasing the competitive advantage of Islamic banks in the financial market. It is believed that VBI can generate a positive and sustainable impact to the economy, community and environment, without compromising the financial returns to shareholders (Ahmad Mukarrami $\mathrm{Ab}$ Mumin, 2018). This indicates that the focus of VBI has been expanded to wider stakeholder management. In the revised Malaysian Code of Corporate Governance (the MCCG 2017), it was stipulated that corporate governance should not only concerned with the rights of investors, but also include meeting the desires of other stakeholders, such as employees, consumers, vendors and the societies in which businesses conduct their business. This is consistent with what has been mentioned in the revised BNM policy documents on Corporate Governance where the board decisions must consider the long-term implications on the financial institution, its customers, employees and the general public. However, literature on corporate governance seem to highlight more on discussing the roles and impacts of corporate governance practices in increasing shareholder values rather than satisfying wider stakeholders' expectations.

\section{Issues and Challenges}

\section{Corporate Governance Reform}

Hasan (2019) argued that VBI needs essential support from corporate governance. In the past, corporate governance highly focused on shareholders' satisfaction with less emphasis on stakeholder management. The existing theory in corporate governance such as agency theory, resource dependency theory and contingency theory also highly discussed on the roles of the corporate governance mechanism towards creating shareholder values and the theories have been extensively applied until today for Islamic banking studies (e.g., Ajili \& Bouri, 2018; Hakimi, Rachdi, Ben Selma Mokni, \& Hssini, 2018; Nomran, Haron, \& Hassan, 2018; Shittu, Ahmad, \& Ishak, 2016). On contrary, Amis, Barney, Mahoney and Wang (2020) argued that today we need a theory of stakeholder governance to reconcile the contradict interest between shareholders and other stakeholders. 


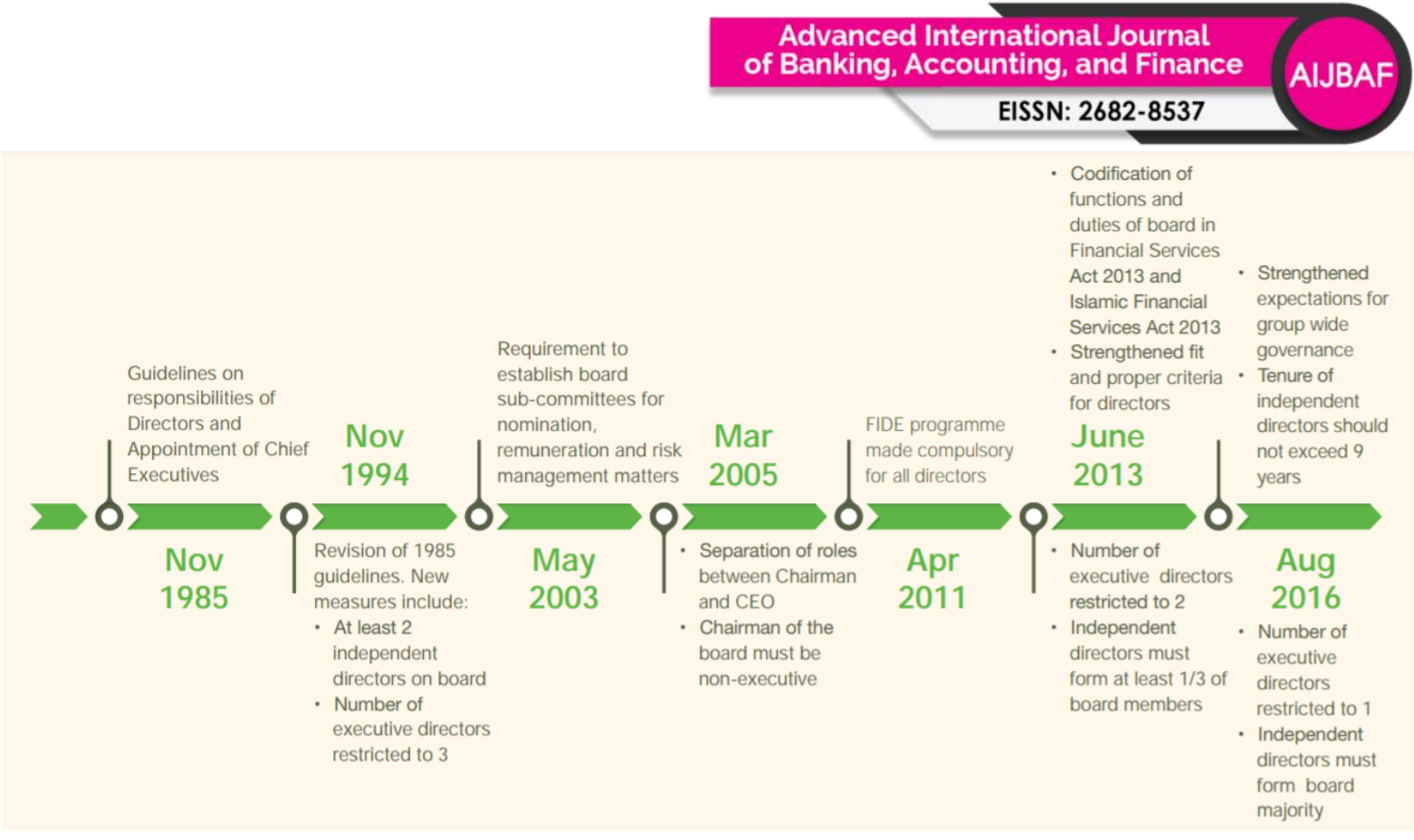

Figure 3: Evolution of Corporate Governance Framework for Financial Institutions Source: Mohammad Khairul Ismail and Abd Aziz (2017)

Corporate governance has gone through several phases of evolution. Especially in Malaysia, continuous revision on code and guidelines of corporate governance can be observed. For example, the Malaysian Code of Corporate Governance (MCCG) has been revised for several times. The first Malaysian Code on Corporate Governance (MCCG) was introduced in 2000 and it has been reviewed in 2007 and 2012. The latest code was revised in 2017 to ensure that it remains relevant and is aligned with the globally recognised best practices and standards. The MCCG has been a significant tool for corporate governance reform and has influenced corporate governance practices of companies positively (MCCG, 2017). In financial sector, the evolution also can be observed in the BNM guidelines on corporate governance. Specifically, the evolution occurred for continuous revision on enhancing board effectiveness through evolution of board composition. Figure 3.1 illustrates the evolution of corporate governance framework for financial institutions in Malaysia. However, as illustrated, evolution in the corporate governance guidelines mostly focussed on increasing the level of independence in the boardroom. Other board characteristics such as board diversity is less emphasised in the previous corporate governance guidelines.

Corporate governance has been incorporated in the practices of various entities including public entities, profit and non-profit organization. Many literatures revealed that corporate governance has a significant influence on firm performance. However, during this time, corporate governance becomes more challenging in the financial system due to the regulatory dynamism and increasing demand on organizational transparency, efficiency, value-oriented and social performance from local and international authorities. In the revised MCCG 2017, the focus has changed. A greater emphasis has been given to sustainability and stakeholder management. A greater emphasis also given not only to board independence, but also board diversity. The role of board independence and board diversity are highlighted in resource dependency theory (Hillman, Cannella, \& Paetzold, 2000). Literature shows that there are several types of board diversity, for example, gender diversity, age diversity, nationality or ethnicity (Bakar, Ghazali, \& Ahmad, 2019; Ercan, 2017). However, the MCCG 2017 focus on gender diversity measured by the proportion of female directors on the board. The code encourages the presence of women directors in board composition to provide greater diversity 
that is expected can offer greater depth and breadth as compared to the non-diverse board. A positive relationship between board diversity and wider stakeholder management has been evidenced by Birindelli, Dell'Atti, Iannuzzi, \& Savioli (2018). Nevertheless, the practice of board diversity in Malaysia is still less popular. The International Finance Corporation reported that only $17 \%$ of board membership in Malaysia are represented by women directors (International Finance Corporation, 2019).

For a Shariah-compliant institutions like Islamic banks, board of directors and Shariah advisors have a shared responsibilities to satisfy the needs of various stakeholders (Hasan, 2019). Among them are to ensure employee welfare in terms of opportunities given, benefit, indemnity and pension, community support like education, investment, health support and qard al-hasan, philanthropic activities like charity, zakat and waqf and many others. An effective operationalization of these functions could ensure the successful implementation of social function and value-based initiative. Nevertheless, deliberation on Shariah advisors' roles towards value-based intermediation are very limited. In the previous and current shariah governance framework (SGF 2010 and SGPD 2019), the objectives of Shariah governance and the role of Shariah advisors are still focussed on ensuring Shariah compliance.

Hasan (2019) has clearly stated the roles of corporate governance reform towards valueoriented practices. In his proposed framework for value-oriented practices, the key stakeholders that are responsible for successful implementation of this strategy are listed. They are the board of directors, shariah board and company manager. Despite lack of deliberation on Shariah board roles towards value-oriented practices in Shariah governance framework and policy documents, Hasan (2019) highlighted few suggestions. According to Hasan (2019), the roles of Shariah board should consists of promoting philanthropy activities, ensuring products and services quality as well as deliberating Shariah issues by taking maqasid al-shariah as the main consideration. In addition, Hassan, Hasan and Ismail (2018) specified five important roles of Shariah board or Shariah committee in promoting VBI and enhancing Islamic banking approach to maqasid al-shariah. The first role is pushing management for VBI initiatives. Second, applying VBI in the product development process. Third, lead or champion VBI initiatives through direct involvement. Fourth, lead awareness and education programs. Fifth monitoring the implementation of VBI. To ensure a proper monitoring to VBI, appointment of Shariah committee as board member could be a useful mechanism. The new BNM policy document on shariah governance has encouraged the appointment of shariah committee member in board to foster closer integration of Shariah governance consideration within the business and risk strategy of the Islamic financial institutions. Nevertheless, this has been less practiced in the board composition of Islamic banks.

\section{Performance Measurement}

Measuring the Islamic banks performance becomes more challenging as to measure its impact to society, economic and environment. Traditionally, profitability, efficiency and growth are the common indicators used to measure firm performance. Research on performance of Islamic banks has been extensively done, but many of them highlighted on creating shareholders' value (see Abbas, Azid, \& Hj Besar, 2016; Hosen \& Muhari, 2017; Shaukat \& Khan, 2018; Zeidan et al., 2013). This paper acknowledges few studies that examined the non-financial aspects such as reporting quality and social contribution (e.g., Rahman \& Jusoh, 2018; Samad, Said, Kamarulzaman, \& Mahshar, 2015; Wan Amalina Wan Abdullah, Percy, \& Stewart, 2013). 
However, their focus was not centralised to maqasid al-shariah. Consequently, quantifying VBI in maqasid perspective also would be much challenging as the nature of maqasid dimension itself is varies (Muhammad et al., 2019). Recently, few studies also proposed a maqasid-based indicator for measuring Islamic bank performance (e.g., Asutay \& Harningtyas, 2015; Mergaliyev, Asutay, Avdukic, \& Karbhari, 2019; Mohammed \& Taib, 2015; Mohammed, Tarique, \& Islam, 2015; Ngalim \& Ismail, 2014; Syafa \& Haron, 2019). These studies were inspired from the first attempt of study by Mohammed et al. (2008). However, operationalizing them into a quantitative measure is quite challenging.

\section{Value-based Performance}

The issuance of VBI Strategy paper by Bank Negara Malaysia (BNM) in March 2018 evidenced that regulator pays serious attention to the ethical practices of Islamic banking industry. Although the introduction of value-based initiative is relatively new, the implementation of some initiative stipulated by VBI has been in place in Islamic banking operation and activities. Therefore, Islamic banks should be fairly assessed by appropriate performance measures to evident Islamic banks' contributions towards wider group of stakeholders. The reliance on conventional performance measure which solely focuses on financial performance is no longer appropriate to be used as performance direction for Islamic banks in Malaysia. The continued adoption of conventional performance measure would also deviate the essential objectives of Islamic banks in upholding the Shariah values.

In one of the consultative documents issued by BNM, a scorecard was introduced to measure Islamic bank performance in realising VBI and maqasid al-shariah. In the proposed scorecard, performance of Islamic banks is measured based on two categories: outcomes and efforts in advancing the VBI agenda. Three performance dimensions are measured in the outcome group such as financial sustainability, level of support to real economy and value creation for wider stakeholders. Meanwhile, in the effort group, it looks into the degree of Islamic banks integrating the key underpinning thrusts of VBI into six aspects namely products and services, human resource tools, performance reporting, leadership, organisational structure and management systems. However, the development and implementation of VBI scorecard also facing its own challenges.

The first challenge is the identification of relevant indicators. It is stated in the consultative document that VBI scorecard looks for more leading indicators that can measure the ongoing efforts of Islamic banks in advancing VBI. However, many of the previous attempts measured Islamic bank performance by using only the lagging indicators that commonly used in measuring firm performances such as profitability and efficiency. Second is the IB readiness to disclose sufficient amount of information for public assessment. Disclosing information in the public report requires more work to be done and it involves more cost to the banks. Nevertheless, choosing an appropriate performance indicator for Islamic banks is crucial as to differentiate the true essence of Islamic banks from the conventional counterpart. Ghayad (2008) argued that a different method should be introduced to measure performance of an Islamic as the level of objectives are divergence from conventional bank.

\section{Conclusion and Suggestions for Future Research}

Islamic banking is currently experiencing a demanding transformation from profit-oriented to value-oriented practices. Even though value-oriented practices has many prospects for Islamic 
banking's growth, it is confronted with several issues and challenges in its implementation. Undoubtedly, realization of maqasid al-shariah and corporate governance readiness are the most crucial of these challenges. There are, nevertheless, a host of other organisational challenges such as establishment of performance direction and identification of appropriate performance measurement for Islamic banks.

Future studies are encouraged to explore how the existing corporate governance theory could address the roles of board and Shariah board in stakeholder management. Intensive studies that explore the possible indicators that can fairly assessed the efforts of Islamic banks in satisfying stakeholder needs are also valuable. This study is a purely based on review of literatures and thus a fieldwork type of research is encouraged to further understand the challenges that they are facing particularly in Malaysia's Islamic financial industry.

\section{References}

Abbas, M., Azid, T., \& Hj Besar, M. H. A. (2016). Efficiency, Effectiveness and Performance Profile of Islamic and Conventional Banks in Pakistan. Humanomics, 32(1), 2-18.

Abdul Aris, N., Othman, R., Mohd Azli, R., Sahri, M., Abdul Razak, D., \& Abdul Rahman, Z. (2013). Islamic Banking Products: Regulations, Issues and Challenges. Journal of Applied Business Research, 25(4), 229-243.

Ahmad Mukarrami Ab Mumin. (2018). VBI: A New Phase for Islamic Banking and Finance in Malaysia. Retrieved September 15, 2020, from Islamic Finance News (IFN) website: https://www.islamicfinancenews.com/vbi-a-new-phase-for-islamic-banking-andfinance-in-malaysia.html

Ajili, H., \& Bouri, A. (2018). Corporate Governance Quality of Islamic Banks: Measurement and Effect on Financial Performance. International Journal of Islamic and Middle Eastern Finance and Management, 11(3), 470-487.

Amis, J., Barney, J., Mahoney, J. T., \& Wang, H. (2020). From the Editors-Why We Need a Theory of Stakeholder Governance-And Why This is a Hard Problem. Academy of Management Review, 45(3), 499-503.

Arshad, R., Muda, R., Nair, R., \& Baharudin, I. (2018). Value-based Intermediation for Islamic Banking Institutions Directed Towards Sustainable Development Goals. International Review of Entrepreneurial Finance, 1(1), 1-17.

Ashur, M. al-T. I. (2006). Treatise on Maqasid al shariah. In The International Institute of Islamic Thought (Vol. 1).

Asutay, M., \& Harningtyas, A. F. (2015). Developing Maqasid al-Shari'ah Index to Evaluate Social Performance of Islamic Banks: A Conceptual and Empirical Attempt. International Journal of Islamic Economics and Finance Studies, 1(1), 5-64.

Bank Negara Malaysia. (2018). Value-based Intermediation: Strengthening the Roles and Impact of Islamic Finance.

Birindelli, G., Dell'Atti, S., Iannuzzi, A. P., \& Savioli, M. (2018). Composition and Activity of the Board of Directors: Impact on ESG Performance in the Banking System. Sustainability (Switzerland), 10(12), 1-20.

BNM. (2018). Implementation Guide for Value-based Intermediation.

Elffie Chew. (2020). Half of Malaysia's Banking Assets to be Islamic in Next Decade. Retrieved September 2, 2020, from Bloomberg website: https://www.bloomberg.com/news/articles/2020-02-02/half-of-malaysia-s-bankingassets-to-be-islamic-in-next-decade 
Febrian, T., Ng, W. S., \& Al Natoor, B. (2019). 2019 Malaysian Islamic Banking Overview: Continued Momentum Amid Regulatory Push. (April), 1-4.

Ghayad, R. (2008). Corporate governance and the global performance of Islamic banks. Humanomics, 24(3), 207-216.

Hakimi, A., Rachdi, H., Ben Selma Mokni, R., \& Hssini, H. (2018). Do Board Characteristics Affect Bank Performance? Evidence from the Bahrain Islamic Banks. Journal of Islamic Accounting and Business Research, 9(2), 251-272.

Hasan, Z. (2019). The Roles of Corporate Governance Towards Value-Oriented Islamic Finance Practices. 'Ulum Islamiyyah, 27(April 2019), 1-17.

Hassan, R. B., \& Nor, F. M. (2019). Value-Based Intermediation: An Analysis from The Perspective of Shariah And Its Objectives. International Journal of Fiqh and Usul AlFiqh Studies, 3(3), 81-89.

Hassan, R., Hasan, A., \& Ismail, M. I. (2018). The Roles of the Shariah Committee in the Implementation of Value-based Intermediation. Retrieved from Islamic Finance News (IFN) website: https://www.islamicfinancenews.com/the-roles-of-the-shariahcommittee-in-the-implementation-of-value-based-intermediation.html

Hillman, A. J., Cannella, A. A., \& Paetzold, R. L. (2000). The Resource Dependence Role of Corporate Directors: Strategic Adaptation of Board Composition in Response to Environmental Change. Journal of Management Studies, 37(2), 235-256.

Hosen, M., \& Muhari, S. (2017). Indicator of Islamic Banking Competitiveness in the Asean Economic Community Era: Case Study of Indonesia and Malaysia. International Research Journal of Finance and Economics, (163).

International Finance Corporation. (2019). Board Gender Diversity in ASEAN.

Kamali, M. H. (2009). Principles of islamic Jurisprudence. Ilmiah Publisher.

Mahadi, N. F., Mohd Zain, N. R., \& Engku Ali, E. R. A. (2019). Leading Towards Impactful Islamic Social Finance: Malaysian Experience with the Value-based Intermediation Approach. Al-Shajarah, October(Special Issue Islamic Banking and Finance 2019), 6987.

Mergaliyev, A., Asutay, M., Avdukic, A., \& Karbhari, Y. (2019). Higher Ethical Objective (Maqasid al - Shari'ah) Augmented Framework for Islamic Banks : Assessing Ethical Performance and Exploring Its Determinants. In Journal of Business Ethics.

Mohammad Khairul Ismail, \& Abd Aziz, A. (2017). Better Boards - The Path Towards Stronger Corporate Governance in Financial Institutions.

Mohammad, M. O., \& Shahwan, S. (2013). The Objective of Islamic Economic and Islamic Banking in Light of Maqasid al-Shariah: A Critical Review. Middle East Journal of Scientific Research, 13(SPLISSUE), 75-84.

Mohammed, M. O., Razak, D. A., \& Taib, F. M. (2008). The Performance Measures of Islamic Banking Based on the The Performance Measures of Islamic Banking Based on the Maqasid Framework. IIUM International Accounting Conference (INTAC IV), PutraJaya Marriott, 1-17.

Mohammed, M. O., \& Taib, F. M. (2015). Developing Islamic Banking Performance Measures based on maqasid Al-Shari'ah Framework: Cases of 24 Selected Banks. Journal of Islamic Monetary Economics and Finance, 1(1), 55-77.

Mohammed, M. O., Tarique, K. M., \& Islam, R. (2015). Measuring the Performance of Islamic Banks using Maqāșid-based Model. Intellectual Discourse, 23(Special Issue), 401-424. Muhammad, A., Bin, I., Khazar, M., Binti, R., Ali, M., Atiqah, N., \& Yusri, B. (2019). Shariah Guideline on Value-Based Intermediation Implementation in the Light of Maqasid 
Shariah Analysis. International Journal of Economics and Management Engineering, 13(4), 2019.

Myers, T. A., \& Hassanzadeh, E. (2013). The Interconnections Between Islamic Finance and Sustainable Finance. In International Institute for Sustainable Development.

Ngalim, S. M., \& Ismail, A. G. (2014). An Islamic Vision Development Based Indicators in Analysing the Islamic Banks Performance: Evidence from Malaysia, Indonesia and Selected GCC Countries.

Nomran, N. M., HaroN, R., \& Hassan, R. (2018). Shari'ah Supervisory Board Characteristics Effects on Islamic Banks' Performance: Evidence from Malaysia. International Journal of Bank Marketing, 36(2), 290-304.

Rahman, N. A., \& Jusoh, M. A. (2018). A Review of Board of Director, Shariah Supervisory Board and Zakat Distribution Performance in Malaysia. International Journal of Academic Research in Business and Social Sciences, 8(2), 785-794.

Ramli, N. M., \& Muhamed, N. A. (2018). Adoption of Value-Based Intermediation through Integrated Reporting: Evidence from Islamic Banks in Malaysia. 6th ASEAN Universities International Conference on Islamic Finance (AICIF).

Samad, K. A., Said, R., Kamarulzaman, M. H., \& Mahshar, M. (2015). Exploring the Zakat Payment and Firm's Performance of Islamic Banks in Malaysia. The 6th International Conference on Governance, Fraud, Ethics and Social Responsibility 2015 (IConGFESR 2015) Exploring.

Shaukat, M., \& Khan, H. C. F. (2018). Measuring the Financial Growth of Islamic Banks and the Compliance to Maqasid Al-Shariah: An Industry Wide Assessment.

Shittu, I., Ahmad, A. C., \& Ishak, Z. (2016). Board Characteristics and Earnings per Share of Malaysian Islamic Banks. International Journal of Economics and Financial Issues, 6(Special Issue), 135-137.

Syafa, A., \& Haron, R. (2019). The Effect of Corporate Governance on Islamic Banking Performance: A Maqasid Shari'ah Index Approach on Indonesian Islamic Banks. Journal of Islamic Finance, 8(Special Issue), 001-018.

Wan Amalina Wan Abdullah, Percy, M., \& Stewart, J. (2013). Shari'ah Disclosures in Malaysian and Indonesian Islamic Banks. Journal of Islamic Accounting and Business Research, 4(2), 100-131.

Zeidan, M. J., Zaini, M., Karim, A., Yahya, M. H., Muhammad, J., Hadi, A. R. A., ... Alslehat, F. (2013). The Financial Performance of Islamic vs Conventional Banks : An Empirical Study on The GCC \& MENA Region. International Journal of Islamic and Middle Eastern Finance and Management, 5(2), 90. 